\title{
БОРИСФЕН
}

УДК 904 (477.7)

DOI: https://doi.org/10.33782/eminak2021.1(33).494

\section{ВУЛИЦІ АРХАЇЧНОГО БОРИСФЕНА}

\author{
Дмитро Чистов \\ Державний Ермітаж (Санкт-Петербург, Російська Федерація) \\ e-mail: d.chistov@gmail.com \\ ORCID: https://orcid.org/0000-0002-6604-5792
}

Стаття присвячена вивченню вуличної мережі Березанського поселення архаїчного періоду. Запропонована нова нумерація вулищь і житлових кварталів, яка може використовуватися у подальших дослідженнях. Робиться висновок про те, що планувальна сітка Борисфена ніколи не була ортогональною, але має ознаки організованого, одночасного планування з уніфікацією ширини вулиць та орієнтацією більшої їх частини за сторонами світу.

Ключові слова: Борисфен, Березанське поселення, грецька колонізація Північного Причорномор'я, міське планування, вулична мережа

3 усіх античних урбанізованих центрів Північного Причорномор'я вулична мережа архаїчного періоду в найкращій мірі вивчена на Березанському поселенні, особливості стратиграфії якого дозволяють досліджувати ранню забудову широкими площами. Суцільні будівельні горизонти наступних епох на цій пам'ятці відсутні, хоча у деяких районах ділянки архаїчних кварталів виявилися сильно зруйновані, або ж перекриті та прорізані більш пізніми спорудами. На території архаїчної колонії у IV - першій половині III ст. до н.е. існувало кілька великих садибних комплексів, рештки яких були виявлені на ділянках «Р1-в», «Г», «0-Східний» (рис. 1, №№ 7, 8, 10 на плані), майже всюди зустрічаються окремі об’єкти класичного (V ст. до н.е.) та римського (II-III ст.) періодів.

Незважаючи на те, що ми поки не маємо цілісної картини просторової організації архаїчного міста другої половини VI - першої третини V ст. до н.е., дослідження останніх десятиліть дозволили суттєво наблизитися до створення достовірної схеми його планування. Значний прогрес у цьому напрямку досягнуто завдяки спільним зусиллям російських та українських археологічних місій по зведенню планів досліджених ділянок на єдину топографічну основу (рис. 1). До отриманої схеми рік від року, по мірі розширення досліджуваної території, систематично вносилися зміниㅜㄹ. Проведена робота і по нанесенню на загальний план найбільш круп-

\footnotetext{
1 Схема на рис. 1 враховує результати розкопок до 2018 р. Раніше публікувалися інші версії цього плану: Chistov D., Krutilov V. The archaic town on the Berezan island: new studies on the chronology
} 
них ділянок розкопок початку XX ст. (рис. 1, №№ 13-16 на плані)², хоча її результатами варто користуватися з певною обережністю через можливі погрішності топографічної прив'язки контурів старих розкопів і неточностей їх планів.

Ці дослідження дозволили внести суттєві корективи до першої схеми архаїчного міста на Березані, розроблена С.Л.Соловйовим на основі даних, які він мав у своєму розпорядженні на початок $1990-\mathrm{x} \mathrm{p.}{ }^{3}$ Нові розкопки підтвердили висновки С.Л. Соловйова про наявність регулярної міської планувальної мережі, яка складалася з системи кварталів, розділених вулицями стандартної ширини, але показали, міське планування Борисфену не було ортогональним. Значні відхилення напрямків вулиць у різних районах міста від осі північ-південь і захід-схід, різна площа та форма міських кварталів роблять неможливою екстраполяцію вже досліджених ділянок планування на всю іншу територію пам'ятки.

До нинішнього часу на території Березанського поселення розкриті кілька великих ділянок житлової забудови архаїчного періоду, в межі яких потрапили частини різних кварталів і відрізки вулиць, які визначаються як такі з різною мірою достовірності. У більшості випадків міські квартали Борисфена досліджені фрагментарно, й їх межі бувають визначені не з усіх сторін. Оскільки загальну кількість вулиць не встановлено, їм неможливо присвоїти номери за порядком. Тому пропонується використовувати умовну нумерацію розкритих повздовжніх (широтних) проспектів (П1, П2...) і поперечних (меридіональних) вулиць (У1, У2...), позначивши буквами латинського алфавіту (A, B, С...) міські квартали, межі яких достовірно виявлені хоча б з двох сторін. У нашій схемі (рис. 2) пронумеровані чотири повздовжніх, широтно орієнтовані вулиці, та дев'ять поперечних; буквені позначки присвоєні десятьом кварталам. 3 подальшим дослідженням Березані ця нумерація може бути продовжена незалежно від того, в якій частині пам'ятки будуть розкриті нові ділянки вулиць і кварталів.

Розуміння планувальної структури урбанізованого Березанського поселення серйозно ускладнюється відсутністю встановлених меж забудови архаїчного періоду. Межу міста в ході розкопок вдалося достовірно виявити лише на заході, оскільки саме там було виявлено незабудований простір між житловими кварталами та некрополем (рис. 1, № 1 на плані)4. Відстань між крайніми будівлями кварталу «С» і могильником на цій ділянці становила всього 40 м. 3 півночі та сходу давні міські вулиці були знищені береговою абразією, а рештки житлових будинків VIV cт. до н.е. з цих сторін підходять впритул до сучасних обривистих берегів. 3 пів-

and urban planning of the Berezan settlement // Phanagoreia und darüber hinaus... Festschrift für Vladimir Kuznetsov / Povalahev N. (Hrsg.). Göttingen: Cuvillier Verlag, 2014. Fig. 2; Chistov D.E. The civic centre of Archaic Borysthenes: a new approach to localization // The Danubian Lands between the Black, Aegean and Adriatic Seas ( $7^{\text {th }}$ Century BC-10 th Century AD). Proceedings of the Fifth International Congress on Black Sea Antiquities / Tsetskhladze G. (ed.). London: Archaeopress, 2015. Fig. 1; Чистов Д.Е., Колесниченко А.Н. Раскопки 1904-1929 гг. в северной части острова Березань: к реконструкции сводного плана исследованных участков Березанского поселения // Боспорские исследования. T. XXXV. Симферополь-Керчь: КФУ им. В.И. Вернадского, 2017. Рис. 8.

2 Чистов Д.Е., Колесниченко А.Н. Раскопки 1904-1929 гг. в северной части острова Березань... C. 444-464.

${ }^{3}$ Solovyov S.L. Ancient Berezan: The architecture, history and culture of the first Greek colony in the Northern Black Sea (Colloquia Pontica. Vol. 4). Leiden: Brill, 1999. P. 78-79, fig. 58.

4 Цей факт був встановлений в ході розширення Північно-західної ділянки (рис. 1, №5 на плані) розвідувальною траншеєю (т. зв. розкоп «Західний») в напрямку некрополя експедицією Державного Ермітажу в 1972-1977 pp. 
дня ж встановленню меж забудованої території перешкоджають експериментальні фортифікаційні споруди початку XX ст. - самі ці будівлі та вибірки грунту, зроблені під час їх зведення, займають практично всю центральну частину острова. Можна бути впевненим, що міська забудова тягнулася на південь від кварталу «Е» «святилища Афродіти» на розкопі «Т» (рис. 1, № 6 на плані): в 90 м на південний захід від нього досліджувався розвідувальний шурф «ЗК» (рис. 3, № 1 на плані) площею близько 25 м², у межах якого була також розкрита кам'яна кладка5. Рештки вимостки виявлені у тому ж районі поселення в межах ще однієї розвідувальної ділянки (рис. 3, № 2 на плані), яка знаходилася приблизно в 40 м на південь від розкопу «Т», або у 50 м на північний схід від «ЗК»6.

Ймовірно, квартальна забудова поширювалася і набагато південніше, а всі фортифікаційні споруди XX ст. виявилася на тій території, яку вона займала у минулому. У 1993 р. на протилежному, східному березі острова, поблизу від експериментальних укріплень, була закладена ділянка «ВК» (рис. 3, № 4 на плані). До меж цього розкопу, який розташований приблизно у 150 м на південь від ділянки «0Восточный», також потрапили рештки архаїчних кам'яно-сирцевих будівель ${ }^{7}$. Сліди кам'яних кладок виявлені й в одному з трьох шурфів, закладених у районі турецьких укріплень у південній частині острова, але античний шар тут був виражений дуже слабко8. Інші дослідження на східному березі у південній частині острову лише трохи додають до цих свідчень. Невеликий (45 м²) розкоп № 11960 р. (рис. 3, № 3 на плані) розміщувався північно-західніше «ВК», приблизно в 60 м по берегу південніше ділянки «0-Восточный». До його меж попали кілька кладок і вимостка, які належали будівельним періодам архаїчної будови 9.

Розвідувальні ділянки, які розміщуються на східному березі далі на південь, будівельних решток вже не виявили. У 1968 р. в обрізі східного берегу досліджувалася господарська яма, яка містила репрезентативні нахідки другої половини VI ст. до н.е. і відходи бронзоливарного виробництва ${ }^{10}$. Найбільш близькою до південного краю острова була ділянка Кз, розкрита Е.Р. фон Штерном у 1907 р. в районі рову турецької та російської фортець ${ }^{11}$. Цей розкоп мав доволі значну площу - він складався з чотирьох паралельних траншей, перша з яких мала розміри 8,53×2,84 м. Тим не менше, будівельні залишки надземних будівель тут були відсутні, хоча знайдені п’ять господарських ям, а культурний шар був насичений східногрецькою й аттичною керамікою.

\footnotetext{
5 Назаров В.В., Паньков С.В., Назарова Т.А., Рудич Т.А. Отчет о раскопках на Березани в 2002 г. Научный архив Института археологии НАН Украины (НА ИА НАНУ). № 2002/144. С. 5-7; Назаров В.В., Паньков С.В., Назарова Т.А. Раскопки на острове Березань в 2002 г. // АВУ 2001-2002. К., 2003. C. 203.

6 Лапин В.В. Отчет о раскопках на о. Березани в 1960 году. НА ИА НАНУ. №1960/11. С. 7-9.

7 Назаров В.В., Якубов В.Н. Отчет о работе Березанской экспедиции в 1993 году. // НА ИА НАНУ. 1992-1993/147. С. 48-57, черт. 2-3.

8 Назаров В.В., Виноградов Ю.Г. Отчет о раскопках на Березани в 1991 г. НА ИА НАНУ №1991/240. C. 30-33.

9 Лапин В.В. Отчет о раскопках на о. Березани в 1960 году. НА ИА НАНУ. №1960/11. С. 3-7.

10 Горбунова К.С. Раскопки на Березани в 1968 году // Науковий архів Інституту археології НАН України. № 1968/37. С. 16-18. На плані С.Л. Соловйова (Solovyov S.L. Ancient Berezan... Fig. 6) ця ділянка позначена під номером 17.

11 Фон Штерн Э.Р. Раскопки на острове Березани // Отчет императорской археологической комиссии за 1907 г. Санкт-Петербург, 1910. С. 73-74. На плані С.Л. Соловйова (Solovyov S.L. Ancient Berezan... Fig. 6) ця ділянка позначена під номером 9 (помилково - як К8).
} 
Виходячи з наведених вище даних, територія міської забудови, ймовірно, простягалася на південь від крайнього північного краю сучасного острова, щонайменше на 320 м (із заходу) і 400 м (зі сходу), а забудовану територію у межах його берегів (без урахування території некрополя) можна оцінити в 10-11 га, або більше. Найважче дати таку оцінку для VI-V ст. до н.е. через відсутність достовірних даних про форму давнього півострова та швидкість берегової абразії. Як показали дослідження В.В. Назарова, розмитий культурний шар продовжується у північному напрямку від урізання води на 50-175 м 12 , тому реальна територія міської забудови архаїчного Борисфена могла у півтора рази перебільшувати вказану вище площу. Для Іонії та материкової Греції VI ст. до н.е. урбанізоване поселення таких розмірів можна вважати порівняно невеликим: за оцінкою Ф.Ланг лише $20 \%$ міських центрів цього часу мали площу менше 10 га, площа ж більшої частини міст, ймовірніше, варіювалася у межах 20-40 га ${ }^{13}$.

Вулична мережа Борисфена, яка виникла близько 540-х рр. до н.е. ${ }^{14}$, проіснувала з мінімальними змінами менше століття - до другої чверті V ст. до н.е., коли більшість мешканців залишили Березанське поселення ${ }^{15}$. Цей не такий вже й тривалий період існування урбанізованого центру може бути, тим не менше, поділений на певні етапи. Дві основні стратиграфічні фази (II-A та II-B) виділяються завдяки пожежам і масовим руйнуванням, які, ймовірно, датуються в рамках останньої чверті VI ст. до н.е. За катастрофічними подіями, причини яких не встановлені, почався новий період будівельної активності. Свідчення перебудов того часу були виявлені в ході археологічних досліджень у різних районах Березанського поселення, причому частіше за все перебудови видозмінювали планування окремих будинків, незначно впливаючи на межі житлових кварталів чи напрямків вулиць ${ }^{16}$.

Наявних на сьогоднішній день даних недостатньо для створення повноцінної моделі планувальної структури Березанського поселення. Разом із тим, їх комплексний розгляд все одно дозволяє зробити низку висновків. Міська забудова Борисфена була, у цілому, орієнтована по лінії північ-південь, але у деяких районах планувальна сітка мала помітне зміщення на південний захід. Особливо це помітно у центральній частині поселення (розкопи «Т», «А1», «Р1-в», «0-Западный»: рис. 1, №№ $6,13,8,9$ ), у той час, як у західній і східній його частинах (розкопи «С3-А» $\mathrm{i}$ «СЗ-Б», «О-Восточный»: рис. 1, №№ 4, 5, 10) орієнтація за сторонами світу витри-

\footnotetext{
12 Назаров В.В. Гидроархеологическая карта черноморской акватории Украины. Киев: Стилос, 2003. C. $48-50$.

${ }^{13}$ Lang F. Archaische Siedlungen in Griechenland: Struktur und Entwicklung. Berlin: Akademie Verlag, 1996. S. 56-57.

14 Чистов Д.Е., Зуев В.Ю., Ильина Ю.И., Каспаров А.К., Новоселова Н.Ю. Исследования на острове Березань в 2005-2009 гг. (Материалы Березанской (Нижнебугской) античной археологической экспедиции. Т.2). Санкт-Петербург: Изд-во Гос. Эрмитажа, 2012. С. 72, 120-121.

15 Копейкина Л.В. Особенности развития поселения на о. Березань в архаический период (по результатам раскопок на северо-западном участке) // Советская археология. 1981. № 1. С. 206-208; Доманский Я.В., Виноградов Ю.Г., Соловьёв С.Л. Основные результаты работ Березанской экспедиции // Итоги работ археологических экспедиций Государственного Эрмитажа. Ленинград: Изд-во Гос. Эрмитажа, 1989. С. 38; Solovyov S.L. Ancient Berezan... P. 98-113; Чистов Д.Е., Ильина Ю.И. Новые данные о Березанском поселении классического периода // OLBIO in memoriam V.V. Krapivina. Київ: IA НАН України, 2015. (Археологія і давня історія України; Вип. 1(14). С. 230250.

16 Solovyov S.L. Ancient Berezan... P. 8, 79; Чистов Д.Е., Зуев В.Ю., Ильина Ю.И., Каспаров А.К., Новоселова Н.Ю. Исследования на острове Березань в 2005-2009 гг.... С. 123.
} 
мувалася більш чітко. Такі відмінності у напрямках вулиць могли бути пов'язані $з$ місцерозташуванням гавані, яка, ймовірно, відповідає сучасній бухті у північносхідній частині острова Березань. Спуск до бухти, як і в нинішній час, міг розташовуватися поблизу давнього перешийку (в районі розкопу «Г»: рис. 1, № 7) - тобто у тому місці, де берег сучасного острову найбільш низький і менш обривистий. Частина меридіональних вулиць у центральній і східній частинах поселення (У-4, У-5, У-6, У-7), ймовірніше, сходилися до гавані під різними кутами; із західного району Борисфена прохід у тому ж напрямку забезпечувався широтними вилицями (ймовірна вулиця П-1, вулиці П-2 і П-3).

Кількість широтно орієнтованих «проспектів», ймовірно, становила не менше п’яти, кількість же меридіональних вулиць була, щонайменше, утричі більшою. Разом із тим, поки незрозуміло, чи були всі широтні «проспекти» дійсно магістральними вулицями, які перетинали всю територію міської забудови із заходу на схід. Наявний план свідчить про те, що у такому випадку вони мали б помітний злам у центральній частині острова (на просторі між розкопами «СЗ-А» и «СЗ-Б» (рис. 1, №№ 4 i 5), і розкопами «Т» и «А1» (№№ 6 і 13), згинаючись відповідно зі зміною напрямків кварталів.

Меридіональні вулиці, як правило, орієнтовані по лінії північ-південь, або мають різні відхилення (від 13 до 34 градусів) на південний захід. Винятком $є$ вулиця У-1, напрямок якої зміщений відносно меридіональної вісі на 13 градусів в інший бік, на південний схід, а також північна частина вулиці У-7, яка підходить під гострим кутом і поєднується із сусідньою У-6.

Припущення С.Л. Соловйова про те, що в оформленні вуличної мережі Березанського поселення простежується певна ієрархія (проспекти шириною до 5 м, поперечні вулиці та провулки шириною до 3,5 і 1,2 відповідно17, поки на знаходить переконливих підтверджень. Лише один відрізок вулиці П-3 має ширину близько 5 м, причому по інший бік перехрестя П-3/У-2 ця ж вулиця має звичайну ширину в 3,5 м. Інша широтна вулиця - П-4 - на ділянці на північ від кварталу «Е» «святилища Афродіти» була вже 1,8-2,4 м у поперечнику18. Ширина вулиці У-9 скоротилась у ході перебудов будинку, що до неї примикає, з 2,8 до 2,2 м, але її можна оцінити лише на порівняно маленькому відрізку ${ }^{19}$. У цілому, в усіх відомих випадках, крім згадуваної вище ділянки П-4, достовірно зафіксовані вулиці Борисфена мають ширину від 2,8 до 3,7 м. Ймовірно, стандартна ширина вулиць, хоч і не дотримувалася точно, мислилася рівною 10-12 іонійським (єгипетським) футам. Всі випадки розкриття провулків шириною до 2 м і менше поки варто віднести до спірних - через недостатність документації, невеликий розмір дослідженої ділянки чи погану збереженість будівельних решток.

Скоріше за все, не можна екстраполювати відмінності у формі добре вивчених кварталів «А» та «В» на сусідні з ними квартали у північній і центральній частинах

\footnotetext{
17 Solovyov S.L. Ancient Berezan... P. 78-79.

18 Крутилов В.В. Раскопки античного поселения на о-ве Березань (участок Т) // Археологічні дослідження в Україні 2008. Київ: IA НАН України, 2009. С. 172.

19 Лапин В.В. Отчет о раскопках древнегреческого поселения на острове Березань (экспедиция археологического музея Института зоологии АН УССР) // Науковий архів Інституту археології НАН України. № 1976/116. С. 22-23; Лапин В.В. Отчет о раскопках древнегреческого поселения на острове Березани экспедицией Киевского государственного университета в 1977 году // Науковий архів Інституту археології НАН України. № 1977/98. С. 13, табл. 22.
} 
острова20. Житловий квартал на південь від «А» та вулиці У-3 досліджений на двох невеликих ділянках, і його форма неясна; але відомо, що розміри та контури розташованого далі на південний схід кварталу «Е», у межах якого знаходиться т. зв. «святилище Афродіти», були зовсім іншими. Оскільки до нинішнього часу на території Березанського поселення відсутні приклади двох сусідніх кварталів однакової форми, важко судити про те, наскільки строго дотримувалася їхня форма та розміри хоча б в окремих районах міста. У північно-східній частині острову розкопками останніх років виявлено квартал «Н», який мав форму прямокутної трапеції: дві меридіонально орієнтовані вулиці У-6 та У-7, які його утворюють, з півночі сходилися під гострим кутом, зливаючись в одну21.

Мережа вулиць у центральній частині Березанського поселення в районі кварталів E, F, G, Н викликає поки надто багато питань, які можуть бути вирішені лише у ході подальших розкопок. Однією з причин цієї невизначеності є будівельні рештки класичного та римського періодів на ділянці «Р-1в» (рис. 1, № 8), які сильно змінили картину архаїчної забудови. Вивчення планів ділянок «ГШ» (№ 12) і «Р1в» (№ 8) дозволяє нам припустити, що їх територію із заходу на схід перетинала вулиця, що мала вигини і при цьому не була одним із широтних «проспектів». Не можна відкидати того, що зі сходу вона підходила до місця з'єднання вулиць У-6 та У-7, а із заходу була пов'язана з вулицею У-4. У такому випадку планування всього цього району не було регулярним. Причини такої (можливо - стихійно складеної?) організації цієї ділянки вуличної мережі незрозумілі; але угрупування великих напівземлянок - т.зв. «домів колоніста» по різні сторони кута вулиць У-6 - У-722 свідчить про те, що це перехрестя існувало з моменту утворення урбанізованого поселення, або навіть дещо раніше.

Квартали неправильних, у т. ч. трикутних контурів, відомі в архаїчній забудові Мегар Гіблейських: вони розташовувались у районі агори, яка ділила місто на дві частини з різним орієнтуванням вуличної мережі. Громадські ж будівлі займали частину житлових кварталів, які виходили на агору23. Ймовірно, що різне орієнтування ділянок квартальної мережі архаїчного Борисфена було також зумовлене як контурами берегової лінії, так і розташуванням міських громадських будівель ${ }^{24}$.

\footnotetext{
20 Пор.: Solovyov S.L. Ancient Berezan... P. 78, fig. 58.

21 Чистов Д.Е., Ильина Ю.И. Исследования экспедиции Государственного Эрмитажа на острове Березань в 2015 году // Археологический сборник Государственного Эрмитажа. Вып. 41. СанктПетербург: Изд-во Гос. Эрмитажа, 2017. С. 177-180, рис. 1-2; Chistov D. Investigations on Berezan Island in 2014-2018 (Hermitage Museum Archaeological Expedition) // Hyperboreus. 2019. Vol. 25. Fasc. 1. P. 97, fig. 1.

22 Чистов Д.Е. Землянки архаической Березани // Північне Причорномор'я за античної доби (на пошану С.Д. Крижицького). Київ: Стародавній світ, 2017. С. 139.

${ }^{23}$ Auberson P., Villard Fr., Vallet G. Mégara Hyblaea. 1. Le quartier de l'agora archaïque. Rome, 1976. Portefeuille 3, plan 11-14; Metraux G. Western Greek land-use and city-planning in the Archaic period. New York - London, 1978. P. 153-156, 168-170, fig. 1; Tréziny H. Archaeological data on the foundation of Megara Hyblaea. Certainties and hypotheses // L. Donnelan, V. Nizzo, G.I. Burgers (eds.). Conceptualizing early colonisation Bruxelles-Rome: Belgisch Historisch Instituut te Rome, 2016. P. 168-170, fig. 1.

${ }^{24}$ Chistov D.E. The civic centre of Archaic Borysthenes: a new approach to localization // The Danubian Lands between the Black, Aegean and Adriatic Seas ( $7^{\text {th }}$ Century BC - 10 th Century AD). Proceedings of the Fifth International Congress on Black Sea Antiquities / Tsetskhladze G. (ed.). London: Archaeopress, 2015. P. 403-413; Bujskikh A., Chistov D. Architectural Details and Monumental Buildings at Borysthenes // Caiete ARA. Vol. 9. București, 2018. P. 12-17.
} 
Хоча межі кварталів, у цілому, залишалися незмінними протягом всього періоду існування Борисфена як урбанізованого центру (тобто у другій половині VI - першої третини V ст. до н.е.) зовнішні стіни будинків після перебудов нерідко зміщувалися, захоплюючи територію вулиць і дещо звужуючи їх. Прикладів же значного зміщення планувальних вісей будов і напрямки примикаючих до них вулиць, поки відомо лише декілька. Так, один із будинків північно-західної частини кварталу G на ділянці «Р-1в» у другій половині VI ст. до н.е. мав майже діагональну орієнтацію по лінії ПдЗх-ПвСх, але зведені поверх його кладок будівлі кінця VI - першої половини V ст. до н.е. розвертаються на 25-35 градусів до меридіональної лінії 25 . Приблизно на 2,5 м зміщується межа вулиці У-7 у центральній частині кварталу Н в ході перебудов того ж часу.

Облаштування вулиць Березанського поселення досить сильно розрізнялося. Кам'яна вимостка з вапнякового буту чи необробленого слощенного каміння зустрічається епізодично. Такі вимостки розкриті на вулицях У-2, У-3, У-6, П-3, у південній частині вулиці У-7 (рис. 4). В інших випадках поверхня вулиці являє собою щільний утоптаний грунт з підсипками з подрібненої кераміки та вапнякової крихти ${ }^{26}$. На вулицях У-2 і П-3 вимостка з черепків, необробленого каміння та дрібного буту поєднувалася з вимостками з більш крупного сплощеного каміння на узбіччях (рис. 5) 27. Товщина шару кам'яно-череп'яної вимостки буває доволі значною: на вулиці П-з вона сягала 0,25 м²8.

Нерідко на просторі вулиць Борисфена простежуються водостоки: їх жолоби, як правило, були оформлені сплощеним, слабко обробленим камінням вапняку, поставленим на ребро. Винятком виглядає відрізок водостоку, облаштованого поблизу східного узбіччя вулиці У-2 (рис.6): він був складений з добре оброблених і

\footnotetext{
25 Будівельні рештки раннього будинку досліджувалися під керівництвом С.М. Мазараті у 1982 р. та Д.Є. Чистова у 2011 р.; пізніх будівель - С.М. Мазараті у 1983-1984 рр.: Мазарати С.Н. Отчет об исследованиях Березанского поселения в 1982 г. // Науковий архів Інституту археології НАН України. № 1982/22. С. 22-23; Мазарати С. Н. Отчет об исследованиях Березанского поселения в 1983 г. // Науковий архів Інституту археології НАН України. № 1983/33. С. 13-19, рис. 81, 17; Мазарати С.Н. Отчет об исследованиях Березанского поселения в 1984 г. // Науковий архів Інституту археології НАН України. № 1984/29Ж. С. 15-18; Крутилов В.В., Чистов Д.Е. Работы экспедиции Государственного Эрмитажа на острове Березань // Археологічні дослідження в Україні 2011. Київ: ІА НАН України, 2012. С. 234.

26 Чистов Д.Е., Зуев В.Ю., Ильина Ю.И., Каспаров А.К., Новоселова Н.Ю. Исследования на острове Березань в 2005-2009 гг... С. 56, 94-95. Ил. 50; Чистов Д.Е., Ильина Ю.И. Исследования экспедиции Государственного Эрмитажа на острове Березань в 2016 году // Археологический сборник Государственного Эрмитажа. Вып. 42. Санкт-Петербург: Изд-во Гос. Эрмитажа, 2019. С. 163; Крутилов В.В., Смирнов А.И. Раскопки античного поселения на о. Березань (участок Т) // Археологічні дослідження в Україні 2009. Київ: IА НАН України, 2010. С. 246.

27 Горбунова К.С., Копейкина Л.В. Отчет о работах Березанской археологической экспедиции Государственного Эрмитажа в 1970 и 1971 гг. // Науковий архів Інституту археології НАН України. № 1970-1971/9-б. С. 21-22. Рис. 22, 38; Копейкина Л.В. Отчет о работе Березанской археологической экспедиции Государственного Эрмитажа в 1972 г. // Науковий архів Інституту археології НАН України. № 1972/83. С. 1-2, рис. 1; Копейкина Л.В. Отчет о работе Березанской археологической экспедиции Государственного Эрмитажа в 1979 г. // Науковий архів Інституту археології НАН України. № 1979/68. С. 12, рис. 2; Копейкина Л.В. Отчет о работе Березанской археологической экспедиции Государственного Эрмитажа в 1980 г. // Науковий архів Інституту археології НАН України. № 1980/84. С. 11-12, план 2.

${ }_{28}$ Соловьев С.Л. Отчет о работе археологической экспедиции Государственного Эрмитажа в 1991 году // Науковий архів Інституту археології НАН України. № 1991/94. С. 18-19.
} 
щільно підігнаних вапнякових плит з підтісуванням у центрі ${ }^{29}$. У кількох випадках водостоки виходять на вулицю з внутрішнього двору будинку. На вулиці У-6 виявлений водостік шириною 0,3-0,6 м, який проходив по центру проїжджої частини на всій ії довжині (рис. 7) 30 - близько 75 м. Обкладки його стінок були оформлені необробленим або грубо відколотим камінням вапняку різної форми. Фактично, мова йде про викопану посередині вулиці канаву, краї якої були досить недбало укріплені камінням; конструкція неодноразово підновлялася. В одному випадку зафіксовано відгалуження, яке відводило стічні води з території кварталу. Ймовірно, таке облаштування каналізації застосовувалося на багатьох вулицях Борисфена: подвійна кладка 86-86¹ на вулиці У-331 північно-західного району поселення безперечно являє собою рештки точно такої ж дренажної системи (рис. 8). Наявний також приклад того, що жолоб водостоку, виходячи з території дому, вигинається та прямує далі вздовж вулиці У-7 (рис. 9) ${ }^{32}$.

Незважаючи на те, що подібні водостоки у наведених прикладах мали досить значну довжину, поки відсутні явні сліди того, що вони могли бути об’єднані в єдину облаштовану дренажну мережу.

Таким чином, Березанське поселення дає нам унікальний, за своєю збереженістю для Північного Причорномор'я, приклад міського планування архаїчного періоду. Ця мережа має ознаки організованого, одночасного планування з уніфікацією ширини вулиць та орієнтацією більшої їх частини за сторонами світу. Тим не менше, вона ніколи не була суворо ортогональною. У цьому сенсі планування Березанського поселення має більше спільного з синхронним йому планом Старої Смирни архаїчного періоду 33 , ніж з чіткою лінійною сіткою «per strigas» колоній Великої Греції VIII-VI ст. до н.е. ${ }^{34}$ Міські квартали Борисфена суттєво відрізнялися розмірами, формами та кількістю будинків, так само як були відмінні за площею та внутрішнім плануванням ділянки зблокованих у ці квартали домогосподарств. Тим не менше, планувальну структуру Березанського поселення можна з повним правом відносити до числа архаїчних центрів із впорядкованим, рядним планом («Reihensiedlung»35): внутрішня площа досліджених кварталів являє собою не конгломерат будівель, як у згадуваній вище Старій Смирні, а правильно організований простір, в якому домогосподарства розташовані у дві лінії, розділені т. зв. «довгою стіною», а сусідні будинки мають спільні стіни та виходи на одну й ту ж вулицю. Подальше вивчення принципів організації цієї мережі, як і планування індивідуальних будинків, може наблизити нас до розуміння базових принципів архаїчної іонійської колонізації й урбанізації в усьому регіоні Північного Понту.

\footnotetext{
${ }^{29}$ Копейкина Л.В. Отчет о раскопках Березанской археологической экспедиции Государственного Эрмитажа в 1977 г. // Науковий архів Інституту археології НАН України. № 1977/94. С. 18, рис. 30. 30 Чистов Д.Е., Ильина Ю.И. Исследования экспедиции Государственного Эрмитажа на острове Березань в 2016 году... С. 163. Ил. 7.

31 Копейкина Л.В. Отчет о работе Березанской археологической экспедиции Государственного Эрмитажа в 1978 г. // Науковий архів Інституту археології НАН України. № 1978/51. С. 4, рис. 2, 4. 32 Чистов Д.Е., Зуев В.Ю., Ильина Ю.И., Каспаров А.К., Новоселова Н.Ю. Исследования на острове Березань в 2005-2009 гг... С. 56.

33 Akurgal E. Alt-Smyrna I. Wohnschichten und Athenatempel. Ankara, 1983. S. 51-56. Abb. 30-31; Lang F. Archaische Siedlungen in Griechenland... S. 235-241, Abb. 106.

${ }^{34}$ Hoepfner W., Schwandner E-L. Haus und Stadt im klassischen Griechenland. München: Deutscher Kunstverlag, 1994. S. 2-4.

35 Lang F. Archaische Siedlungen in Griechenland... S. 60-62.
} 


\section{REFERENCES}

Akurgal, E. (1983). Alt-Smyrna I. Wohnschichten und Athenatempel. Ankara.

Auberson P., Villard Fr. \& Vallet G. (1976). Mégara Hyblaea. 1. Le quartier de l'agora archaïque. Rome: École Française de Rome.

Bujskikh, A. \& Chistov, D. (2018). Architectural Details and Monumental Buildings at Borysthenes. In Caiete ARA (Vol. 9, pp. 5-22). București.

Chistov, D.E. (2015). The civic center of Archaic Borysthenes: a new approach to localization. In Tsetskhladze, G. (Ed.). The Danubian Lands between the Black, Aegean and Adriatic Seas (7th Century $B C-10^{\text {th }}$ Century AD). Proceedings of the Fifth International Congress on Black Sea Antiquities (pp. 403413). London: Archaeopress.

Chistov, D.E. (2017). Zemlianki arkhaicheskoi Berezani [Pit houses of the archaic Berezan settlement]. In Pivnichne Prychornomor'ia za antychnoi doby (na poshanu S.D. Kryzhytskoho). (pp. 127-144). Kyiv: Starodavnii svit [in Russian].

Chistov, D. (2019). Investigations on Berezan Island in 2014-2018 (Hermitage Museum Archaeological Expedition). Hyperboreus, Vol. 25. Fasc. 1, 97-106.

Chistov, D.E. \& Ilyina, Yu.I. (2015). Novye dannye o Berezanskom poselenii klassicheskogo perioda [New data on the Berezan settlement during Classical period]. In Arkheolohiia i davnia istoriia Ukrainy, 1 (14): OLBIO in memoriam V.V. Krapivina, 230-250 [in Russian].

Chistov, D.E. \& Ilyina, Yu.I. (2017). Issledovaniia ekspeditsii Gosudarstvennogo Ermitazha na ostrove Berezan v 2015 godu [Research of the State Hermitage expedition on the Berezan Island in 2015]. Archeologicheskii sbornik Gosudarstvennogo Ermitazha (Vol. 41, pp.177-216). Sankt-Petersburg [in Russian].

Chistov, D.E. \& Ilyina, Yu.I. (2019) Issledovaniia ekspeditsii Gosudarstvennogo Ermitazha na ostrove Berezan v 2016 godu [Research of the State Hermitage expedition on the Berezan Island in 2016]. Archeologicheskii sbornik Gosudarstvennogo Ermitazha (Vol. 42, pp. 155-171). Sankt-Petersburg [in Russian].

Chistov, D.E. \& Kolesnichenko, A.N. (2017). Raskopki 1904-1929 gg. v severnoi chasti ostrova Berezan: $\mathrm{k}$ rekonstruktsii svodnogo plana issledovannykh uchastkov Berezanskogo poseleniia [Excavations of 1904-1929 in the Northern part of Berezan Island: to the reconstruction of the consolidated plan of the investigated areas of the Berezan Settlement]. Bosporskie issledovaniia (Vol. XXXV, pp. 444-464). Simferopol-Kerch [in Russian].

Chistov, D. \& Krutilov, V. (2014). The archaic town on the Berezan Island: new studies on the chronology and urban planning of the Berezan Settlement. In Povalahev, N. (Hrsg.). Phanagoreia und darüber hinaus... Festschrift für Vladimir Kuznetsov. Göttingen: Cuvillier Verlag.

Chistov, D.E., Zuev, V.Yu., Ilyina, Yu.I., Kasparov, A.K. \& Novoselova, N.Yu. (2012). Issledovaniia na ostrove Berezan v 2005-2009 gg. [Research on the Berezan island in 2005-2009]. (Series: Materialy Berezanskoi Nizhnebugskoi antichnoi arkheologicheskoi ekspeditsii. Vol. 2). Sankt-Petersburg: Izdvo Gos Ermitazha [in Russian].

Domanskii, Ya.V., Vinogradov, Yu.G. \& Solovev, S.L. (1989). Osnovnye rezultaty rabot Berezanskoi ekspeditsii [Main results of the Berezan expedition]. Itogi rabot arkheologicheskikh ekspeditsii Gosudarstvennogo Ermitazha (pp. 33-60). Leningrad: Izd-vo Gos. Ermitazha [in Russian].

Hoepfner, W. \& Schwandner, E-L. (1994). Haus und Stadt im klassischen Griechenland. München: Deutscher Kunstverlag.

Kopeikina, L.V. (1981). Osobennosti razvitiia poseleniia na o. Berezan v arkhaicheskii period (po rezultatam raskopok na severo-zapadnom uchastke] [Features of the development of the settlement on Berezan Island in the archaic period (according to the results of excavations in the North-Western sector)]. Sovetskaia arkheologiia, 1, 192-208 [in Russian].

Krutilov, V.V. (2009). Raskopki antichnogo poseleniia na ostrove Berezan (uchastok T) [Excavations of the ancient settlement on the Berezan Island (sector T)]. Arkheolohichni doslidzhennia $v$ Ukraini of 2008, (pp. 171-174). Kyiv: IA NAN Ukrainy [in Russian].

Krutilov, V.V. \& Chistov, D.E. (2012). Raboty ekspeditsii Gosudarstvennogo Ermitazha na ostrove Berezan [Research of the State Hermitage expedition on the Berezan Island]. Arkheolohichni doslidzhennia v Ukraini of 2011, (pp. 233-235). Kyiv: IA NAN Ukrainy [in Russian].

Metraux, G. (1978). Western Greek land-use and city-planning in the Archaic period. New York - London: Garland Pub.

Nazarov, V.V. (2003). Gidroarkheologicheskaia karta chernomorskoi akvatorii Ukrainy [Hydroarchaeological map of the Black Sea waters of Ukraine]. Kyiv: Stylos [in Russian].

Nazarov, V.V., Pankov, S.V. \& Nazarova, T.A. (2003). Raskopki na ostrove Berezan v 2002 g. 
[Excavations on the Berezan Island in 2002]. Arkheolohichni doslidzhennia v Ukraini 2001-2002, (p. 203). Kyiv: IA NAN Ukrainy [in Russian].

Shtern fon, E.R. (1910). Raskopki na ostrove Berezani [Excavations on Berezan Island]. Otchet Imperatorskoi archeologicheskoi komissii za $1907 \mathrm{~g}$. (pp. 66-75). Sankt-Petersburg [in Russian].

Solovyov, S.L. (1999). Ancient Berezan: The architecture, history and culture of the first Greek colony in the Northern Black Sea (Series: Colloquia Pontica. Vol. 4). Leiden: Brill.

Tréziny, H. (2016). Archaeological data on the foundation of Megara Hyblaea. Certainties and hypotheses. In Donnelan, L., Nizzo, V. \& Burgers, G.I. (Eds.). Conceptualizing early colonization, (pp. 167-178). Bruxelles-Rome: Belgisch Historisch Instituut te Rome.

\section{Dmitriy Chistov}

(The State Hermitage Museum, Sankt-Petersburg, Russian Federation)

e-mail: d.chistov@gmail.com

ORCID: https://orcid.org/0000-0002-6604-5792

\section{Streets of Archaic Borysthenes}

The street layout of the archaic period of all the ancient urban centers of the Northern Black Sea region is best studied on the materials of Berezan settlement. At the same time, many settlement blocks are only partially open, and the total number of streets has not been found out. Therefore, it is offered to use conventional numbering of the opened longitudinal (latitudinal) avenues and transverse (meridional) streets, applying the letters of the Latin alphabet for settlement blocks in which bounds are reliably revealed from at least two sides. Berezan street layout, which originated around 540s BCE, has the signs of organized, simultaneous planning. But it was never strictly orthogonal.

The streets were paved with stones, limestone crumbs, and shards; in some cases, drains ran along them, which, however, were not integrated into one drainage system. Urban built-up area was generally oriented north-south, but in some areas, the planning layout had a marked shift to the southwest. Differences in the street orientation could be depended on the location of the ancient harbor or the public center of the archaic colony.

Keywords: Borysthenes, Berezan settlement, Greek colonization of the Northern Black Sea coast, urban planning, street layout 


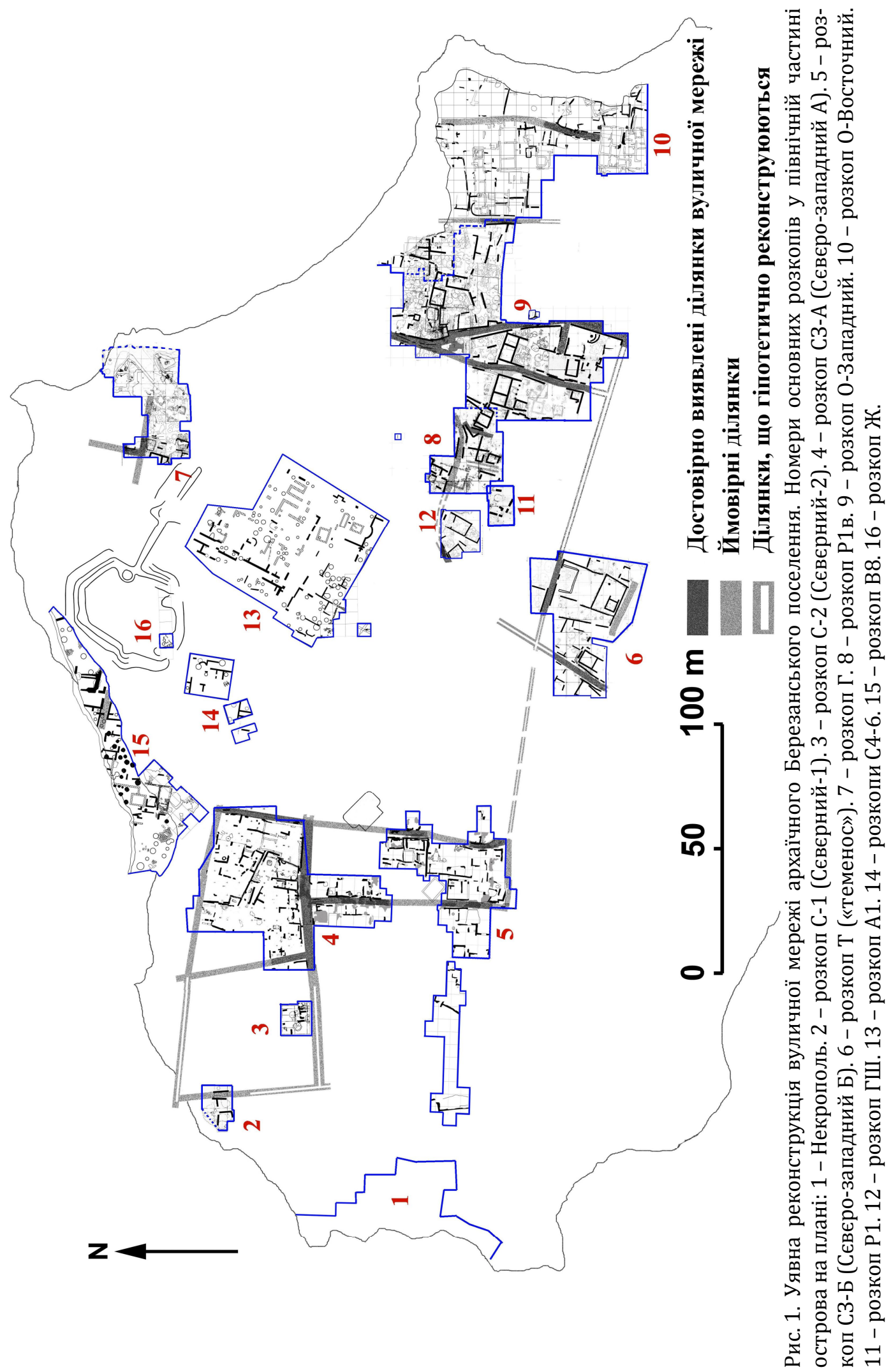




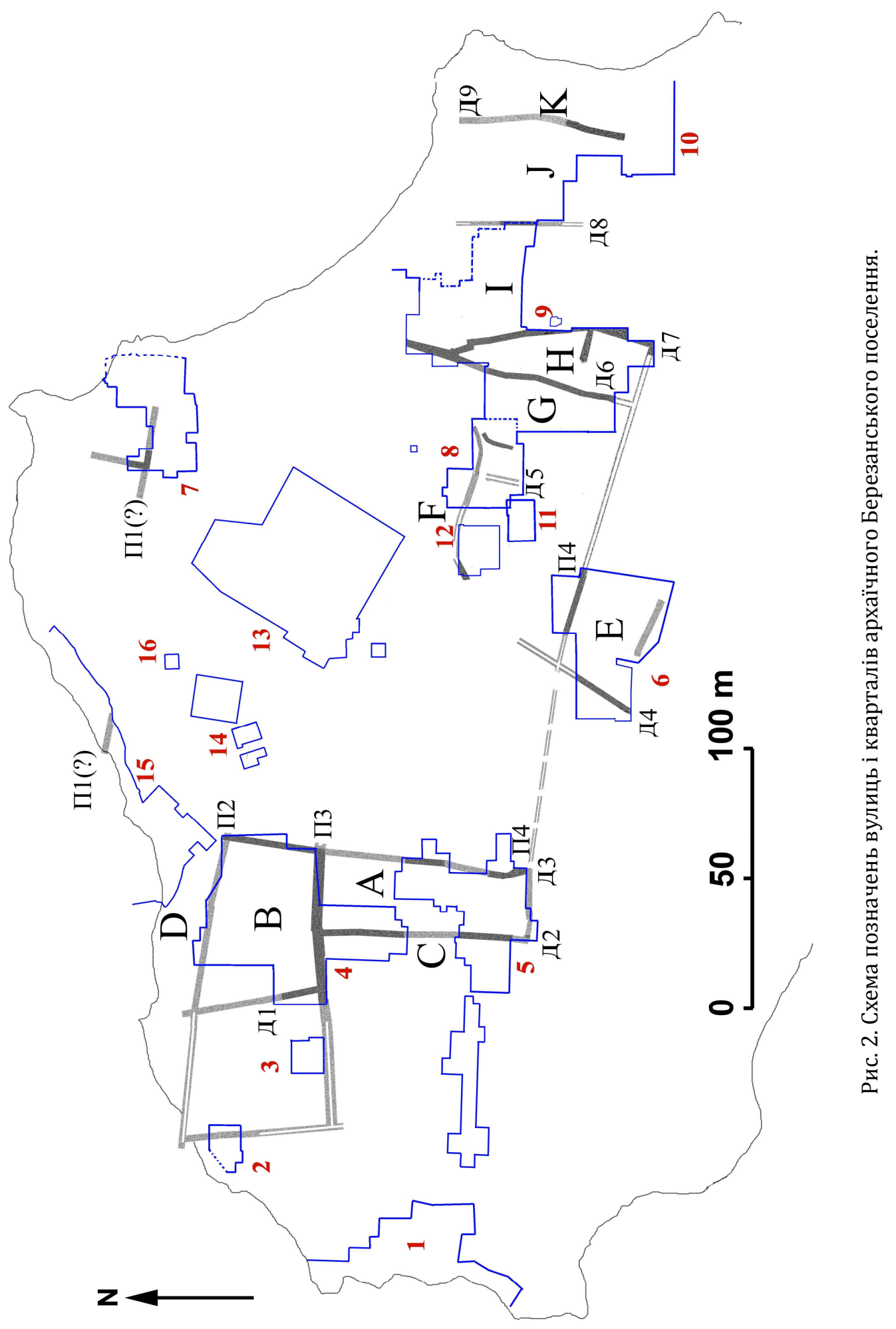




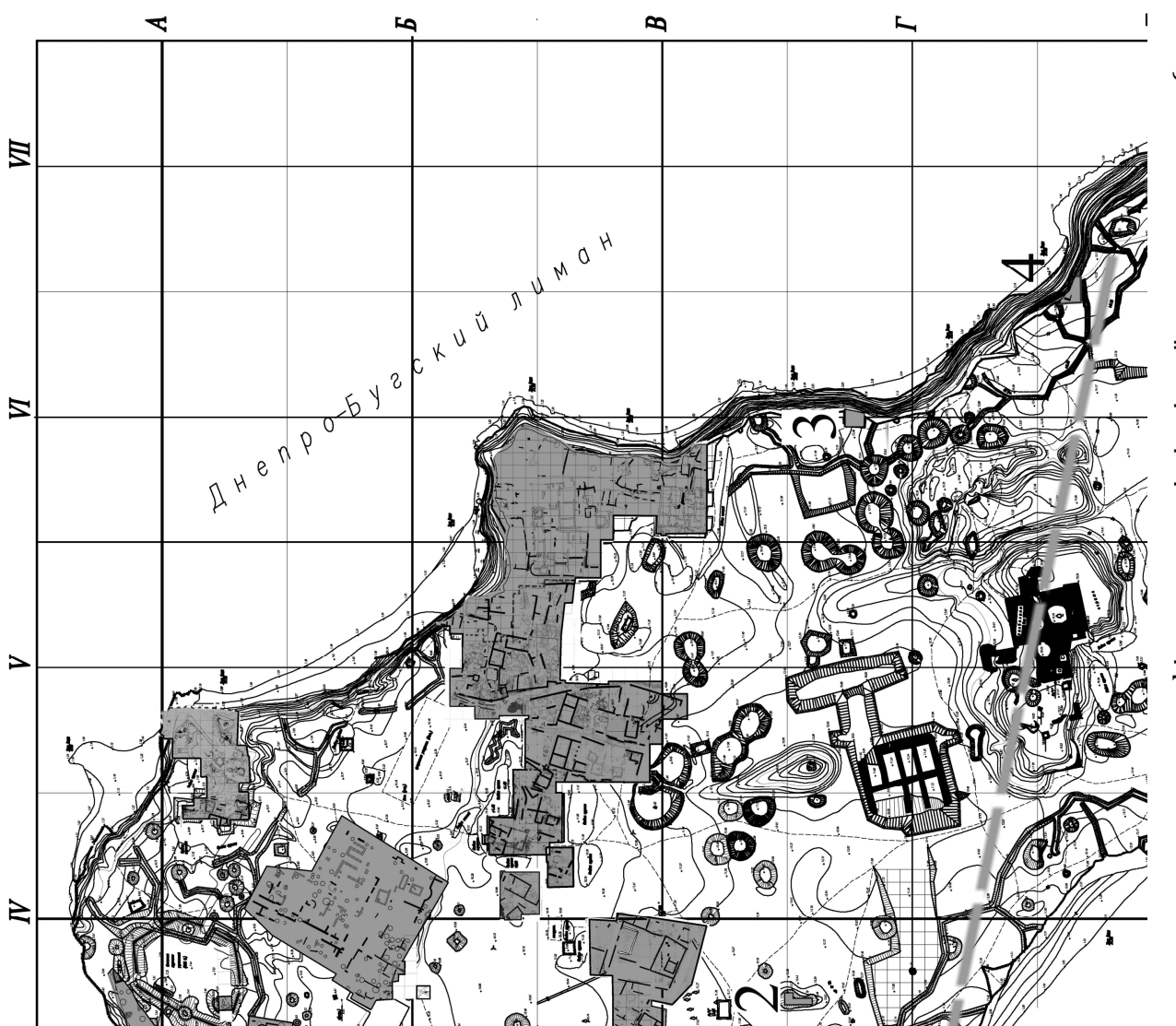

完完

更济

㻤

응

¿

至

敋

ซ

:

满各

目质

王

피 1

政

这

욱요

50

Q 는

语

음

式

준

政

定定

焉

․ㅛㅇ

인

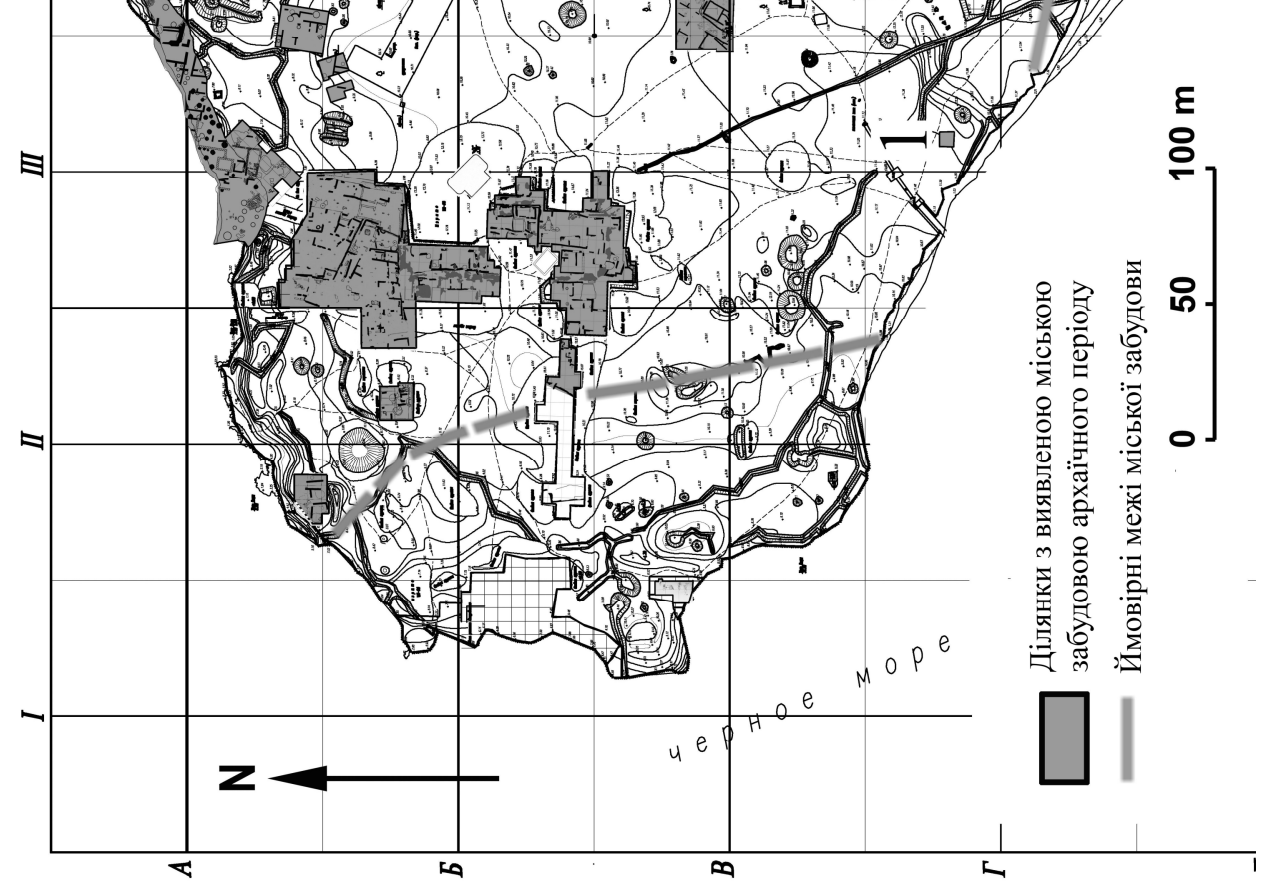

ㅇ.

원

远

응 읍

ํํ용

일

응

ن

웅오

学

ช 2

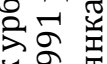

ชิ

这。

$\times$ ।

产员

点

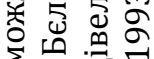

范合路

ये

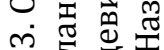

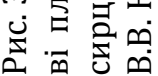




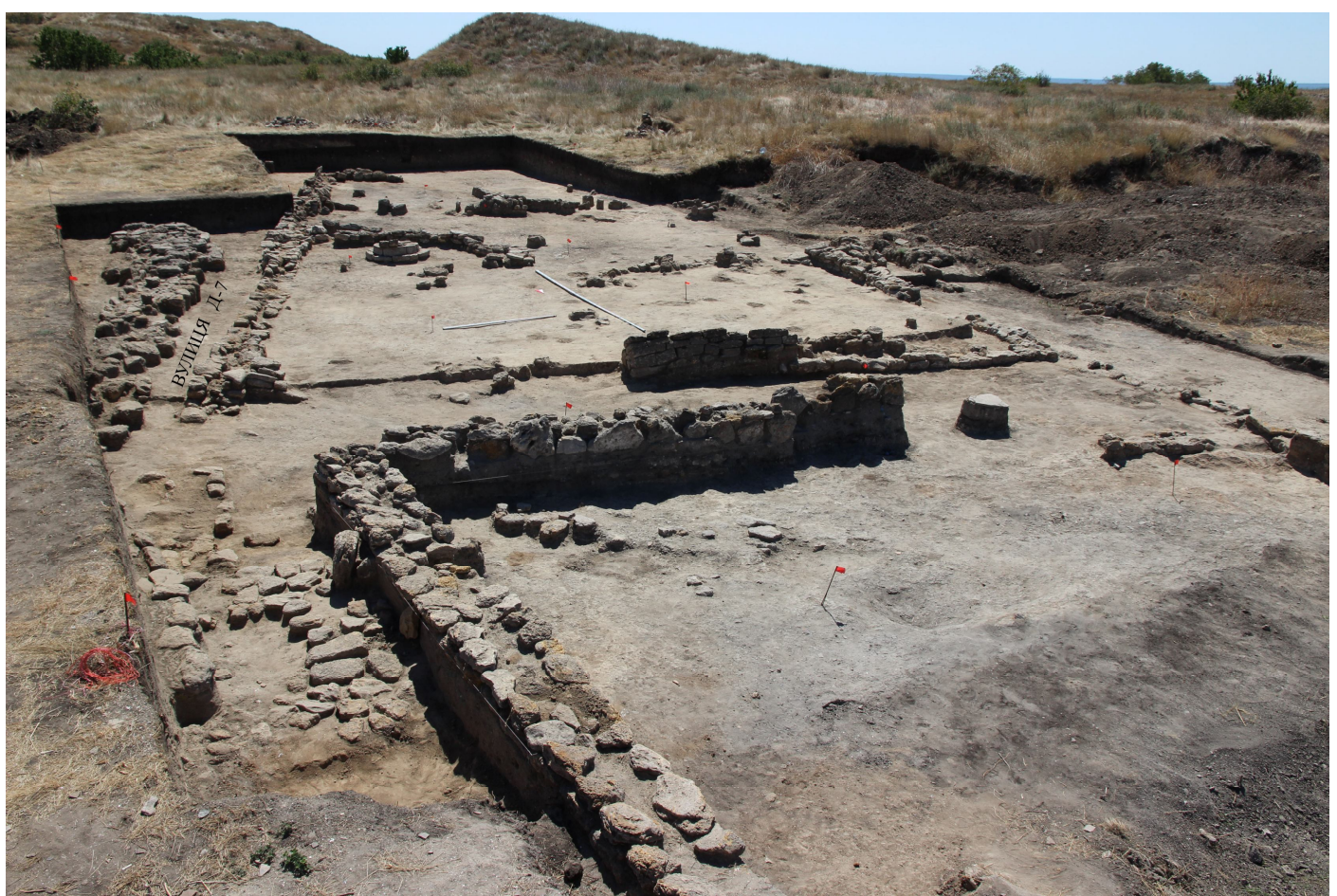

Рис. 4. Кам'яна вимостка вулиці У-7 (зліва) та південно-східна частина кварталу «Н». Вид з півночі.

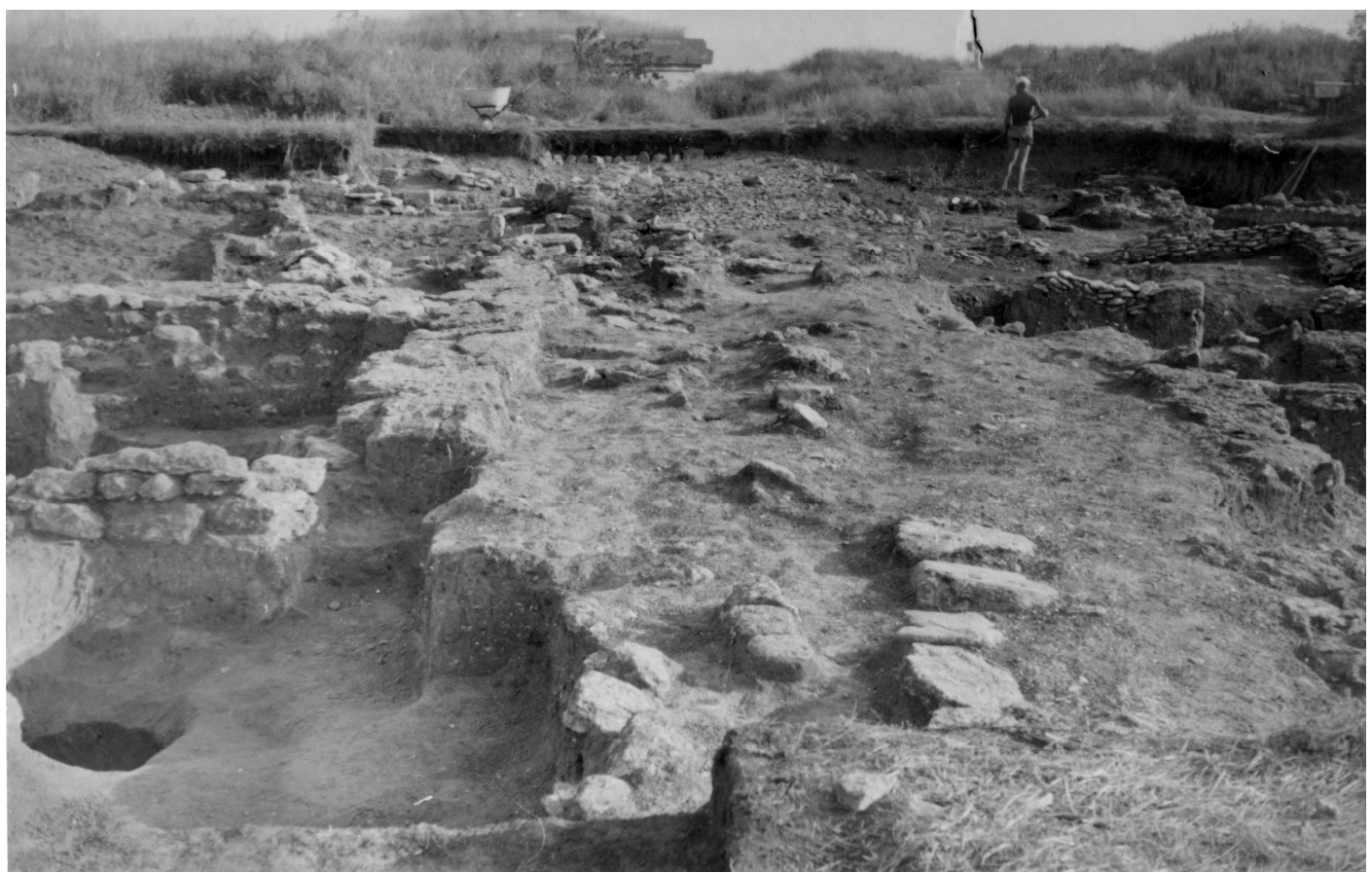

Рис. 5. Північний відрізок вулиці У-2. Вид з півночі. Л.В. Копєйкіна, 1979 р. 


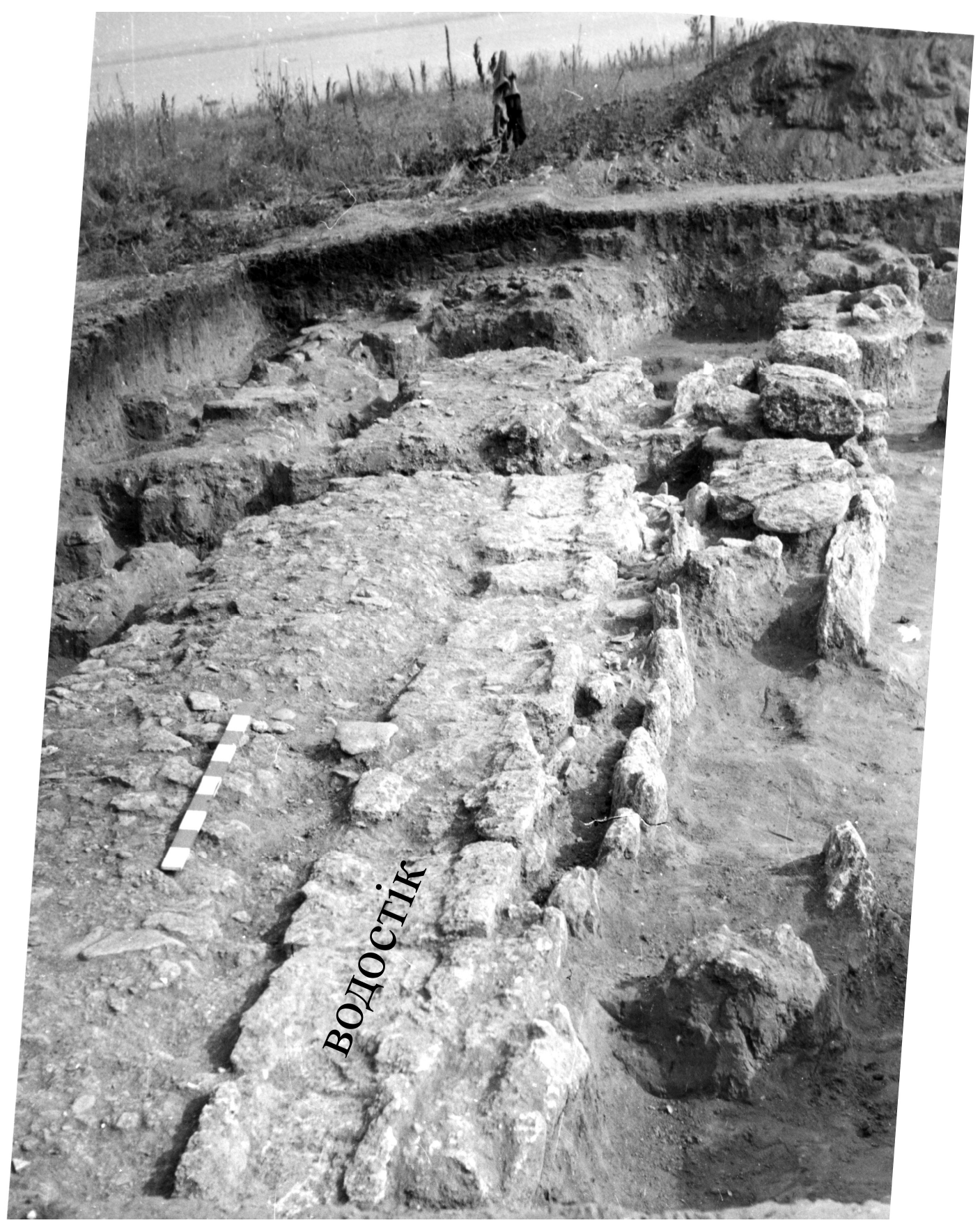

Рис. 6. Північний відрізок вулиці У-2 та водостік вздовж її східного краю. Вид з південного сходу. Л.В. Копєйкіна, 1977 р. 


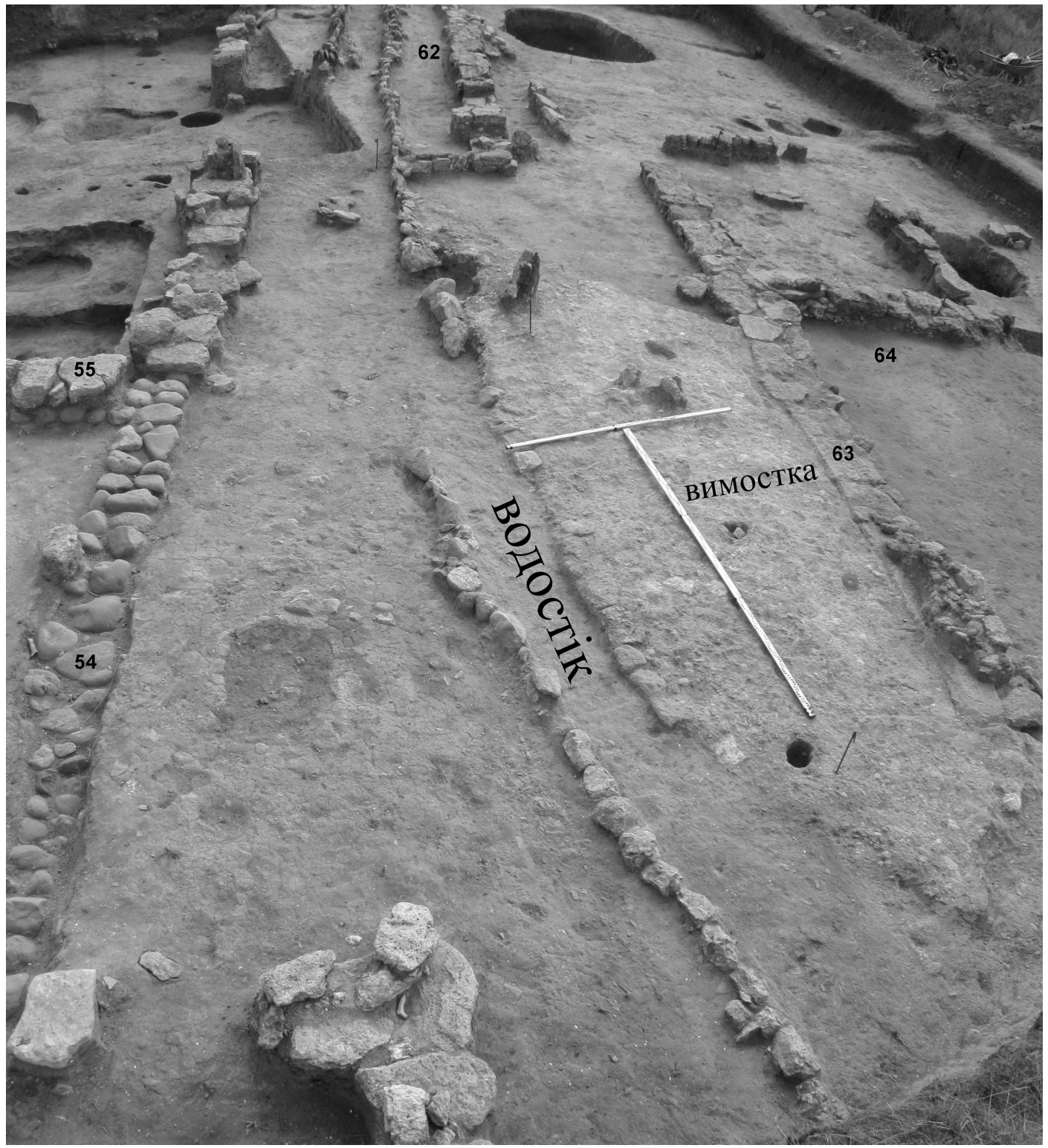

Рис. 7. Ділянка пізньоархаїчної вимостки та водостоку вулиці У-6 між громадськими будівлями в кварталах «G» $\mathrm{i}$ «Н». 


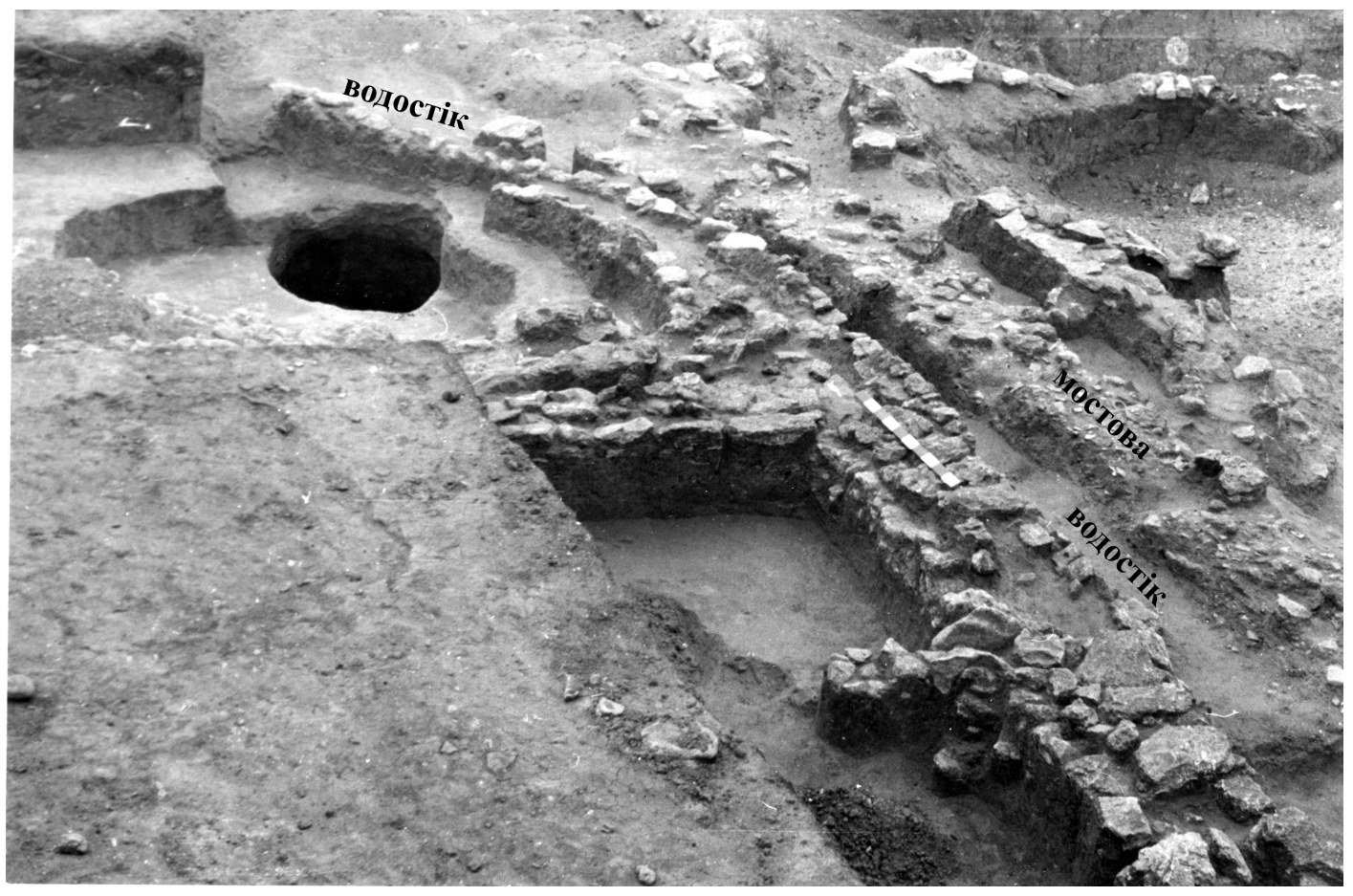

Рис. 8. Південна ділянка вулиці У-3, вид з півночі. Водостік, який проходить з півночі на південь, вигинається на схід на перехресті з вулицею П-4. Л.В. Копєйкіна, 1978 р.

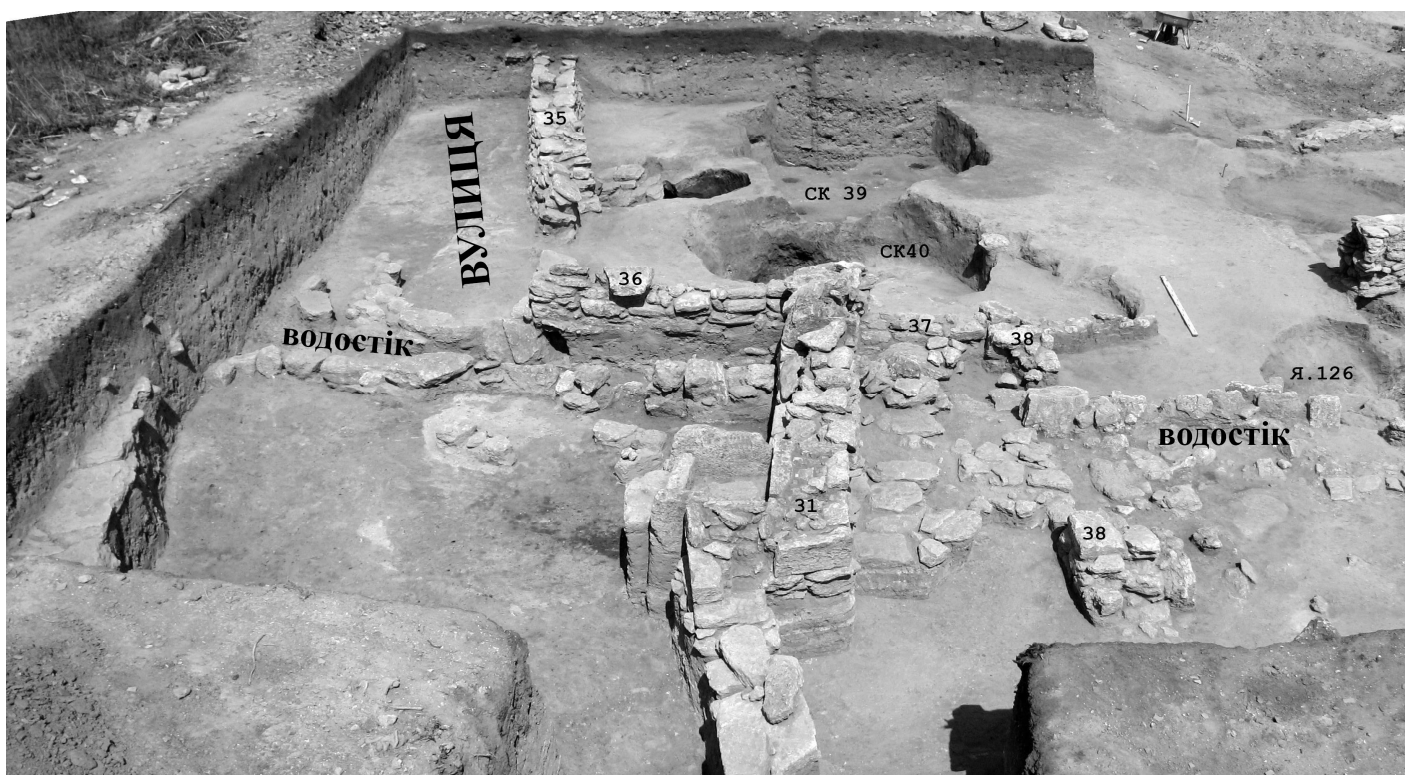

Рис. 9. Водостік, який проходить з двору житлового будинку кварталу «I» через протирон на вулицю. 